\title{
Tikagrelor lekiem przeciwpłytkowym pierwszego wyboru w ostrym zespole wieńcowym. Czy w Polsce są realizowane wytyczne terapii przeciwpłytkowej u chorych z ACS?
}

\author{
Ticagrelor antiplatelet drug as first choice in patients with acute \\ coronary syndrome. Are there guidelines focused on dual antiplatelet \\ therapy applied in practice in Polish patients with ACS?
}

\author{
Beata Wożakowska-Kapłon \\ I Klinika Kardiologii i Elektroterapii Świętokrzyskiego Centrum Kardiologii \\ Wydział Lekarski i Nauk o Zdrowiu Uniwersytetu Jana Kochanowskiego w Kielcach
}

\section{Streszczenie}

Podwójna terapia przeciwpłytkowa, czyli połączenie kwasu acetylosalicylowego i jednego z inhibitorów P2Y ${ }_{12}$, jest obecnie standardem postępowania w ostrych zespołach wieńcowych. Tikagrelor jest przedstawicielem nowej grupy leków przeciwpłytkowych, bezpośrednim, działającym niekompetycyjnie inhibitorem receptorów P2Y ${ }_{12}$. Badania farmakokinetyki tikagreloru wskazują na szybsze i silniejsze niż klopidogrel działanie hamujące agregację płytek. Skuteczność i bezpieczeństwo tikagreloru w porównaniu z klopidogrelem udowodniono zarówno w badaniu randomizowanym (16-proc. redukcja ryzyka zgonów sercowo-naczyniowych, zawałów i udarów [współczynnik ryzyka $\{H R\}$ 0,84; 95-proc. przedział ufności $\{\mathrm{Cl}\}$ 0,77-0,92], 21-proc. redukcja ryzyka śmiertelności sercowo-naczyniowej [HR 0,79; 95\% Cl 0,69-0,91; $p=0,001]$, brak znamiennie statystycznych różnic w poważnych krwawieniach v. klopidogrel [11,6\% v. 11,2\%; $p=0,43]$ ), jak i w badaniu RWE opartym na rejestrze Swedeheart. Według aktualnych wytycznych Europejskiego Towarzystwa Kardiologicznego zaleca się wybór tikagreloru spośród innych inhibitorów receptora $\mathrm{P}_{2 \mathrm{Y}_{12}}$ bez względu na początkową strategię leczenia. Korzyści z zastosowania tikagreloru uzyskuje się w przypadku wyboru strategii leczenia: zachowawczej, angioplastyki bądź operacyjnej.

Słowa kluczowe: tikagrelor, ostre zespół wieńcowy

Folia Cardiologica 2018; 13, 5: 442-449

\section{Wstęp}

Według danych pochodzących z Narodowej Bazy Danych Zawałów Serca AMI-PL (ogólnopolski rejestr obejmujący > 500 tys. osób) w 2014 roku w Polsce zawał serca bez uniesienia odcinka ST (NSTEMI, non-ST-elevation myocardial infarction) i z uniesieniem odcinka ST (STEMI, ST-elevation myocardial infarction) stwierdzono u 76030 osób (u 40810 NSTEMI, u 32699 STEMI), największą grupę pacjentów stanowili mężczyźni (62\%) i osoby w wieku 60-64 lat (13 377 osób) [1]. Według danych z Ogólnopolskiego Rejestru Ostrych Zespołów Wieńcowych PL-ACS (obejmującego > 600 tys. osób) w 2014 roku średnia wieku osób ze STEMI wynosiła około 66 lat, a z NSTEMI 69 lat. Stwierdzono też nieznaczny trend spadkowy, jeśli chodzi o liczbę rozpoznanych zawałów serca, natomiast

Adres do korespondencji: prof. dr hab. n. med. Beata Wożakowska-Kapłon, I Klinika Kardiologii i Elektroterapii, Świętokrzyskie Centrum Kardiologii, ul. Grunwaldzka 45, 25-736 Kielce, e-mail: bw.kaplon@poczta.onet.pl 
odnotowano: wzrost liczby rozpoznań NSTEMI, a zmniejszenie - STEMI. Podobne tendencje obserwuje się w Europie i Stanach Zjednoczonych [1].

W Polsce w 2015 roku śmiertelność wewnątrzszpitalna wyniosła 10,5\% w przypadku STEMI i 7,3\% w przypadku NSTEMI, przy czym jedną z głównych przyczyn zgonów był wstrząs kardiogenny [1]. Dużą śmiertelność z powodu ostrych zespołów wieńcowych (ACS, acute coronary syndrome) stwierdza się zwłaszcza w przypadku kobiet, u których częściej niż u mężczyzn występują nietypowe objawy dławicy (nawet u 30\%) [2], co opóźnia rozpoczęcie leczenia [3, 4]. Na śmiertelność w przypadku zawału serca ma też wpływ to, jak szybko chory trafi do szpitala dysponującego pracownią hemodynamiki. Niestety, aż około $30 \%$ pacjentów z ACS nie trafia w optymalnym czasie do ośrodka kardiologicznego [5].

Ryzyko zgonu związane z ACS nadal pozostaje znaczne, chociaż rokowanie dotyczące przeżycia po zawale serca poprawiło się w ciągu ostatnich lat: w 2004 roku śmiertelność wewnątrzszpitalna wynosiła 15\%, w 2015 roku 10\%; w ciągu roku po zawale zaś, odpowiednio: $24 \%$ i $18 \%$ [1]. Polepszenie rokowania dotyczącego przeżycia w ACS było możliwe dzięki powszechnemu stosowaniu pierwotnej angioplastyki, a także nowoczesnego leczenia przeciwzakrzepowego i przeciwpłytkowego [6, 7].

Niezwykle ważnymi mechanizmami chorobowymi leżącymi u podłoża ACS są aktywacja kaskady krzepnięcia i powstawanie zakrzepów w świetle naczynia [8]. Proces ten rozpoczynają adhezja i agregacja płytek krwi w miejscu uszkodzonego (pęknięcie lub nadżerka blaszki miażdżycowej) śródbłonka naczynia, w którym rozwinęła się miażdżyca, lub na powierzchni materiałów pochodzenia egzogennego, na przykład protezy wewnątrznaczyniowej [8]. Powstające zakrzepy mogą powodować: zmniejszenie światła naczynia, zawał serca, udar i zakrzepicę naczyń obwodowych, dlatego też w ACS stosuje się leki przeciwpłytkowe, hamujące agregację płytek krwi [8].

Jednymi z najważniejszych leków przeciwpłytkowych w ACS są doustne inhibitory płytkowego receptora purynergicznego $\mathrm{P} 2 \mathrm{Y}_{12}$ dla adenozyno-5'-difosforanu (ADP, adenosine diphosphate): pochodne tienopirydyny, czyli klopidogrel i prasugrel, a także należący do cyklopentylotriazolopirymidyn tikagrelor [9].

\section{Wytyczne terapii przeciwpłytkowej obowiązujące u chorych z ACS}

Obecnie standardem postępowania w ACS jest podwójne leczenie przeciwpłytkowe (DAPT, dual antiplatelet therapy), czyli połączenie wzajemnie uzupełniających się leków wpływających na dwa najważniejsze szlaki aktywacji płytek: kwasu acetylosalicylowego (ASA, acetylsalicylic acid) $\mathrm{i}$ jednego $\mathrm{z}$ inhibitorów P2Y $\mathrm{Y}_{12}$ [10-12]. W aktualnych wytycznych Europejskiego Towarzystwa Kardiologicznego
(ESC, European Society of Cardiology), opublikowanych w 2015 roku „Wytycznych ESC dotyczących postępowania w ostrych zespołach wieńcowych bez przetrwałego uniesienia odcinka ST" [10] oraz opublikowanych w 2017 roku „Wytycznych ESC dotyczących postępowania w ostrym zawale serca z uniesieniem odcinka ST" [11] i "Uaktualnionym stanowisku ESC dotyczącym stosowania podwójnej terapii przeciwpłytkowej w chorobie wieńcowej" [12], zaleca się stosowanie DAPT przez 12 miesięcy u pacjentów z ACS, niezależnie od wyboru strategii postępowania: leczenia zachowawczego, przezskórnej interwencji wieńcowej (PCI, percutaneous coronary intervention) czy pomostowania aortalno-wieńcowego (CABG, coronary artery bypass grafting). Autorzy wytycznych wskazują tikagrelor, przy braku przeciwwskazań (przebyte krwawienie wewnątrzczaszkowe lub czynne krwawienie), jako lek pierwszego wyboru wśród inhibitorów $\mathrm{P}_{2} \mathrm{Y}_{12}$, bez względu na początkową strategię leczenia. U chorych z ACS zaleca się podanie tikagreloru w dawce nasycającej $180 \mathrm{mg}$, następnie w dawce $90 \mathrm{mg}$ 2 razy/dobę. Jeśli pacjent otrzymuje klopidogrel, należy go odstawić i rozpocząć podawanie tikagreloru (klasa zaleceń I, poziom wiarygodności danych B). Klopidogrel może zostać włączony, jeśli nie ma możliwości podania tikagreloru.

\section{Farmakokinetyka inhibitorów receptora $\mathrm{P}_{2} \mathrm{Y}_{12}$}

Klopidogrel występuje w formie proleku, który musi być metabolizowany do formy aktywnej w wątrobie za pomocą cytochromu P450, dlatego też jego działanie rozpoczyna się 2-4 godziny po podaniu [13]. Tikagrelor występuje w formie aktywnej i początek jego działania stwierdza się już po 30 minutach [13]. Lek ten wiąże się w odwracalny sposób z receptorem $\mathrm{P} 2 \mathrm{Y}_{12}$, dzięki czemu po przerwaniu przyjmowania tikagreloru o wiele szybciej powraca prawidłowa funkcja płytek krwi niż w przypadku klopidogrelu [13]. Działanie tikagreloru utrzymuje się kilkanaście godzin. Klopidogrel nieodwracalnie modyfikuje płytkowy receptor $\mathrm{P} 2 \mathrm{Y}_{12}$, a jego działanie utrzymuje się aż do wyprodukowania nowych płytek, czyli około 7 dni [13].

W wynikach badania ONSET-OFFSET potwierdzono, że tikagrelor szybciej i silniej niż klopidogrel powoduje zahamowanie działania płytek krwi [14]. W tym wieloośrodkowym, randomizowanym badaniu z podwójnie ślepą próbą uczestniczyło 123 pacjentów z rozpoznaniem stabilnej dusznicy bolesnej przyjmujących ASA w dawce 75-100 mg/dobę. Zostali oni losowo przydzieleni do jednej z trzech grup, które otrzymywały przez 6 tygodni: tikagrelor (początkowa dawka nasycająca $180 \mathrm{mg}$, dawka podtrzymująca $90 \mathrm{mg} 2 \times / \mathrm{d}$.); klopidogrel (początkowa dawka nasycająca $600 \mathrm{mg}$, dawka podtrzymująca $75 \mathrm{mg}$ $\mathrm{raz} / \mathrm{d}$.); placebo. Zaobserwowano szybszy początek - po półgodzinie od podania dawki nasycającej - działania 
tikagreloru w porównaniu z klopidogrelem. Silniejsze hamowanie aktywności płytek (IPA, inhibition of platelet aggregation) stwierdzono w grupie osób przyjmujących tikagrelor w porównaniu z grupą otrzymującą klopidogrel po półgodzinie, godzinie, 2, 4, 8, 24 h i 6 tygodniach po podaniu dawki nasycającej leków ( $p=0,0001$ ). Po 2 h od podania dawek nasycających leków 50-procentowe IPA stwierdzono u 98\% pacjentów z grupy leczonej tikagrelorem (70-proc. IPA u 90\%) w porównaniu z 31\% pacjentami w grupie leczonej klopidogrelem (70-proc. IPA u 16\%) (w obu przypadkach $\mathrm{p}<0,0001$ ). Powrót aktywności płytek krwi był szybszy w przypadku stosowania tikagreloru. Dobę po podaniu ostatniej dawki leku średnie IPA w grupie leczonej tikagrelorem wynosiło 58\% oraz w grupie leczonej klopidogrelem - 52\% (wynik nieistotny statystycznie), w kolejnych dobach stwierdzono szybszy powrót aktywności płytek w grupie przyjmującej tikagrelor.

Polimorfizm genów izoenzymów CYP może być przyczyną, że stwierdza się zmienną indywidualną odpowiedź na klopidogrel, a u niektórych osób lek ten nie działa z odpowiednią skutecznością [15]. Wysoką reaktywność płytek krwi podczas leczenia (HTPR, high-on treatment platelet reactivity) obserwuje się, w zależności od badań, u 15-50\% przyjmujących klopidogrel osób, co prowadzi do zwiększenia u nich ryzyka powikłań niedokrwiennych i zakrzepicy w stencie [16]. Na odpowiedź na leczenie klopidogrelem wpływają też takie czynniki, jak wiek, wysoki wskaźnik masy ciała (BMI, body mass index), cukrzyca, niewydolność nerek i palenie tytoniu [16].

W badaniu RESPOND (Response to Ticagrelor in Clopidogrel Nonresponders and Responders and Effect of Switching Therapies) dowiedziono, że tikagrelor powoduje wystarczające do uniknięcia incydentów niedokrwiennych zahamowanie działania płytek krwi w grupie osób, które są oporne na działanie klopidogrelu (tzw. non-responders) [17]. W tym randomizowanym, podwójnie zaślepionym badaniu chorujący na stabilną dusznicę bolesną pacjenci oporni na klopidogrel $(n=41)$ i wrażliwi na ten lek $(n=57)$ zostali losowo przydzieleni do grupy otrzymującej przez 14 dni klopidogrel (w dawce nasycającej $600 \mathrm{mg}$, następnie $75 \mathrm{mg}$ raz/d.) lub tikagrelor (w dawce nasycającej $180 \mathrm{mg}$, następnie $90 \mathrm{mg} 2$ ×/d.). Następnie osoby oporne na działanie klopidogrelu podzielono na kolejne dwie grupy - jedna z nich kontynuowała przyjmowanie tego samego leku, druga natomiast zmieniła go na inny (klopidogrel na tikagrelor i tikagrelor na klopidogrel). W grupie osób opornych na klopidogrel przyjmującej tikagrelor stwierdzono silniejsze zahamowanie aktywności płytek krwi w porównaniu z klopidogrelem ( $p<0,05)$. Ponadto stwierdzono, że zdolność do agregacji płytek krwi zmniejszyła się (z $59 \pm$ $\pm 9 \%$ na $35 \pm 11 \%$ ) u pacjentów, którym zamieniono klopidogrel na tikagrelor, a zwiększyła (z $36 \pm 14 \%$ na 56 土 9\%) u pacjentów, którym tikagrelor zamieniono na klopidogrel (w obu przypadkach $\mathrm{p}<0,0001$ ).
Skuteczność i bezpieczeństwo tikagreloru w randomizowanych, wieloośrodkowych badaniach klinicznych

W wieloośrodkowym, randomizowanym, podwójnie zaślepionym badaniu PLATO (PLATelet inhibition and patients Outcomes) porównano skuteczność i bezpieczeństwo tikagreloru podawanego chorym z ACS przez 12 miesięcy w dawce $90 \mathrm{mg}$ 2 razy/dobę z klopidogrelem w dawce 75 mg raz/dobę [18] W badaniu uczestniczyło 18624 osób przyjętych do szpitala z powodu NSTE-ACS (z zaplanowanym postępowaniem zachowawczym albo inwazyjnym) lub ze STEMI (zakwalifikowanych do pierwotnej PCl). Pacjentów przydzielono losowo do grupy przyjmującej klopidogrel $75 \mathrm{mg}$ raz/dobę (dawka nasycająca 300-600 mg) lub do grupy leczonej tikagrelorem w dawce $90 \mathrm{mg} 2 \mathrm{razy} /$ dobę (dawka nasycająca $180 \mathrm{mg}$ ). U wszystkich pacjentów stosowano też ASA. Osoby poddawane PCl mogły również otrzymać dodatkową zaślepioną dawkę nasycającą klopidogrelu 300 mg (całkowita dawka nasycająca $600 \mathrm{mg}$ ) lub placebo i mieli również zalecenie przyjmowania dodatkowej dawki $90 \mathrm{mg}$ tikagreloru (lub placebo), jeśli upłynęła doba od zastosowania wyjściowej dawki nasycającej. Prawie 50\% pacjentów z grupy leczonej tikagrelorem było wstępnie leczonych klopidogrelem. Leczenie trwało do 12 miesięcy z medianą 9 miesięcy.

Pierwszorzędowy złożony punkt końcowy (zgon z przyczyn naczyniowych, zawał serca lub udar mózgu) wystąpił u 9,8\% pacjentów z grupy przyjmującej tikagrelor i 11,7\% pacjentów z grupy przyjmującej klopidogrel (współczynnik ryzyka [HR, hazard ratio] 0,84; 95-proc. przedział ufności [Cl, confidence interval] 0,77-0,92), co stanowiło istotna statystycznie różnice ( $p<0,001)$. Istotne statystycznie różnice między grupą przyjmującą tikagrelor a grupą przyjmującą klopidogrel stwierdzono też w przypadku częstości zgonów z przyczyn naczyniowych: 4\% w porównaniu z 5,1\% (HR 0,79; 95\% Cl 0,69-0,91; $p=0,001$ ), a także częstości zawału serca: 5,8\% w porównaniu z 6,9\% (HR 0,84; 95\% Cl 0,75-0,95; $p=0,005)$, natomiast nie wykazano ich w przypadku częstości udaru mózgu (1,5\% v. 1,3\%; $p=0,22)$. Obserwowano również zmniejszenie częstości występowania zakrzepicy w stencie: z 1,3\% do 1,9\% ( $p=0,009)$, a także śmiertelności całkowitej: z 4,5\% do $5,9 \%$ ( $p<0,001)$. Na taką przewagę tikagreloru nad klopidogrelem wskazywano zarówno u pacjentów poddawanych $\mathrm{PCl}$, leczonych zachowawczo, jak i chorych, u których przeprowadzono CABG. Nie stwierdzono istotnych statystycznie różnic między grupami, jeśli chodzi o poważne krwawienia (11,6\% v. 11,2\%; $p=0,43)$. Terapia tikagrelorem wiązała się jednak ze zwiększeniem częstości poważnych krwawień niezwiązanych z CABG (4,5\% v. 3,8\%, p=0,03). Przewage leczenia tikagrelorem nad klopidogrelem wykazano też bez względu na ostateczne rozpoznanie (NSTEMI, STEMI) $[19,20]$, a także sposób leczenia (leczenie inwazyjne lub zachowawcze) [21, 22]. 
W subanalizie przeprowadzonej przez zespół Husteda [23] stwierdzono, że na skuteczność i bezpieczeństwo tikagreloru nie ma również wpływu wiek przyjmujących go osób z ACS. W grupie osób starszych ( $\geq 75$. rż.) uczestniczących w badaniu PLATO częstość występowania pierwszorzędowego punku końcowego nie różniła się w porównaniu ze stwierdzanym w grupie osób młodszych ( $p$ dla interakcji $=0,56$ ). Podobną zależność stwierdzono $\mathrm{w}$ przypadku wystąpienia: zawału serca ( $p=0,33)$, zgonu z przyczyn sercowo-naczyniowych $(p=0,47)$, zakrzepicy w stencie $(p=0,81)$ i zgonu z dowolnej przyczyny $(p=0,76)$. W obu grupach nie stwierdzono zwiększenia częstości poważnych krwawień: u osób w wieku 75 lat i starszych: HR był równy 1,02, 95\% Cl 0,82-1,27; u osób poniżej 75 lat (HR 1,04, 95\% Cl 0,94-1,15). Skuteczność i bezpieczeństwo stosowania tikagreloru oceniono też w kilku subanalizach z badania PLATO dotyczących podgrup pacjentów szczególnie narażonych na powikłania niedokrwienne i krwotoczne.

W subanalizie przeprowadzonej przez Jamesa i wsp. [24] przeanalizowano dane 4662 chorych na cukrzyc, stwierdzając w grupie otrzymującej tikagrelor w porównaniu z grupą otrzymującą klopidogrel zmniejszenie występowania pierwszorzędowego złożonego punktu końcowego (14,1\% v. 16,2\%, HR 0,88, 95\% Cl 0,76-1,03), zgonu z dowolnej przyczyny (7,0\% v. 8,7\%, HR 0,82, 95\% Cl 0,66-1,01) i zakrzepicy w stencie $(1,6 \%$ v. $2,4 \%$, HR $0,65,95 \%$ Cl 0,36-1,17) [24]. Nie stwierdzono zwiększenia częstości poważnych krwawień (14,1\% v. 14,8\%; HR 0,95; 95\% Cl 0,81-1,12).

Podobne wyniki stwierdzono w subanalizie 3237 pacjentów z przewlekłą chorobą nerek (klirens kreatyniny $<60 \mathrm{ml} / \mathrm{min}$ ) [25]. W tej grupie tikagrelor w porównaniu z klopidogrelem znacząco zmniejszał częstość występowania pierwszorzędowego złożonego punktu końcowego (17,3\% v. 22,0\%, HR 0,77, 95\% Cl 0,65-0,90). Co więcej, bezwzględne zmniejszenie ryzyka było większe u osób z przewlekłą chorobą nerek niż u osób z prawidłową funkcją tego narządu (7,9\% v. 8,9\%, HR 0,90, 95\% Cl 0,79-1,02), znacznie zmniejszyła się też całkowita śmiertelność (10,0\% v. 14,0\%, HR 0,72, 95\% Cl 0,58-0,89). Częstość poważnych krwawień nie istotnie różniła się w obu grupach (15,1\% v. 14,3\%, HR 1,07, 95\% Cl 0,88-1,30).

W badaniu PEGASUS-TIMI 54 (Prevention of Cardiovascular Events in Patients with Prior Heart Attack Using Ticagrelor Compared to Placebo on a Background of Aspirin-Thrombolysis in Myocardial Infarction) oceniano skuteczność i bezpieczeństwo długotrwałej terapii tikagrelorem w dawce $90 \mathrm{mg}$ lub $60 \mathrm{mg} 2 \mathrm{razy} /$ dobę [26]. Do badania włączono 21162 pacjentów, u których uprzednio (przed rokiem do 3 lat wstecz) wystapił zawał serca. Wszystkie te osoby były obciążone dużym ryzykiem wystąpienia chorób naczyniowo-sercowych. Badanych podzielono losowo na trzy grupy: przyjmującą tikagrelor w dawce 90 mg 2 razy/dobę, przyjmującej tikagrelor w dawce $60 \mathrm{mg} 2$ razy/dobę lub do grupy otrzymującej placebo. Dodatkowo wszyscy pacjenci otrzymywali ASA w dawkach 75-150 mg/dobę. Mediana czasu obserwacji wynosiła 33 miesiące. Stwierdzono istotne statystycznie rzadsze występowanie pierwszorzędowego złożonego punktu końcowego (zgon z przyczyn sercowo-naczyniowych, zawał serca lub udar mózgu) w obu grupach otrzymujących tikagrelor w porównaniu z grupą przyjmującą placebo: $7,85 \%$ w grupie przyjmującej $90 \mathrm{mg}$ tikagreloru, 7,77\% w grupie przyjmującej $60 \mathrm{mg}$ tikagreloru, 9,04\% w grupie otrzymującej placebo (dla $90 \mathrm{mg}$ v. placebo: HR 0,85, 95\% $\mathrm{Cl} 0,75-0,96 ; p=0,008$; dla 60 mg v. placebo: HR 0,84, $95 \% \mathrm{Cl} 0,74-0,95 ; p=0,004)$. W grupie otrzymującej tikagrelor stwierdzono także istotne statystycznie zmniejszenie częstości zawału serca (obie grupy przyjmujące tikagrelor v. placebo; dla 90 mg v. placebo: HR 0,81, 95\% $\mathrm{Cl} 0,69-0,95 ; p=0,01$; dla 60 mg v. placebo HR 0,84, 95\% Cl 0,72-0,98; $p=0,03$ ) i udaru mózgu (grupa przyjmująca mniejszą dawkę tikagreloru v. placebo: HR 0,75, 95\% Cl 0,57-0,98; $p=0,03)$.

Poważne krwawienia według skali TIMI (Thrombolysis in Myocardial Infarction) występowały znacząco częściej wśród osób przyjmujących tikagrelor (2,6\% dla grupy przyjmującej 90 mg i 2,3\% dla 60 mg) w porównaniu z grupą przyjmującą placebo (1,06\%) (dla $90 \mathrm{mg}$ tikagreloru v. placebo: HR 2,69, 95\% Cl 1,96-3,70; $p<0,001$; dla 60 mg tikagreloru v. placebo: HR 2,32, 95\% Cl 1,68-3,21; $p<0,001)$. Nie stwierdzono jednak istotnego wpływu między czasem przyjmowania leku a ryzykiem krwawienia. Podobne wyniki uzyskano zarówno u pacjentów ze STEMI, jak i z NSTEMI.

Przedstawiono też subanalizę badania PEGASUS-TIMI 54, w której wykazano 20-procentowe zmniejszenie ryzyka wystąpienia pierwszorzędowego punktu końcowego (HR 0,80, 95\% Cl 0,70-0,91; p=0,001), 29-procentowe zmniejszenie ryzyka zgonu z przyczyn sercowo-naczyniowych (HR 0,71, 95\% Cl 0,56-0,90; p =0,0041) i 20-procentowe obniżenie ryzyka zgonu z dowolnej przyczyny (HR 0,80, 95\% Cl 0,67-0,96; p = 0,018) w populacji 10779 pacjentów z ACS otrzymujących tikagrelor w dawce $60 \mathrm{mg} 2 \mathrm{razy} /$ dobę jako kontynuację leczenia przez rok tikagrelorem w dawce $90 \mathrm{mg} 2$ razy/dobę [27]. Do badania włączono także osoby, u których leczenie rozpoczęto do 2 lat po zawale serca lub w ciągu roku od zaprzestania leczenia poprzednim inhibitorem receptora ADP.

Wykorzystując dane 18761 osób włączonych do badania PEGASUS-TIMI 54, sprawdzono również hipotezę wskazująca, że pacjenci, którzy dopiero niedawno przerwali leczenie inhibitorem $\mathrm{P} 2 \mathrm{Y}_{12}$ po zawale serca, są obciążeni większym ryzykiem wystąpienia niepożądanych zdarzeń sercowych i bardziej skorzystają z przedłużonej terapii tikagrelorem niż osoby, które już dawno przerwały terapię inhibitorem $\mathrm{P}_{2} \mathrm{Y}_{12}$ i było u nich skuteczne leczenie samym ASA [28]. Badanych podzielono na grupy według czasu, 
który upłynął od ostatniego przyjęcia inhibitora $\mathrm{P} 2 \mathrm{Y}_{12}$ : nie dłuższy niż 30 dni, w ciągu 30-360, powyżej 360. Stwierdzono, że korzyści z przyjmowania tikagreloru zależą od czasu, który minął od przyjęcia ostatniej dawki tego leku. Współczynnik ryzyka $(95 \% \mathrm{Cl})$ dla połączonych dawek tikagreloru w porównaniu z placebo wynosił, odpowiednio: $0,73(0,61-0,87), 0,86(0,71-1,04)$ i $1,01(0,80-1,27)$, tendencja $p$ dla interakcji poniżej 0,001 . W badaniu wykazano też, że tikagrelor ma największą skuteczność w przypadku pacjentów kontynuujących terapię lub wznawiających ją jedynie po krótkiej przerwie.

W opublikowanej w 2017 roku metaanalizie przeprowadzono porównanie skuteczności i bezpieczeństwa klopidogrelu, prasugrelu i tikagreloru, wykorzystując dane z 9 randomizowanych badań klinicznych, w których łącznie uczestniczyło 106288 pacjentów z ACS (CLARITY-TIMI-28 [Clopidogrel as Adjunctive Reperfusion Therapy-TIMI-28], COMMIT [CIOpidogrel and Metoprolol in Myocardial Infarction Trial], CURE [Clopidogrel in Unstable Angina to Prevent Recurrent Events], DISPERSE-2 [Dose Confirmation Study Assessing Anti-Platelet Effects of AZD6140 vs Clopidogrel in NSTEMI 2], PHILO [PHase the International Study of TicagreLor and Clinical Outcomes in Asian ACS Patients], PLATO, PRASFIT-ACS [PRASugrel Compared to Clopidogrel For Japanese PatlenTs with ACS Undergoing PCl], TRILOGY-ACS [Targeted Platelet Inhibition to Clarify the Optimal Strategy to Medically Manage Acute Coronary Syndromes], TRITON-TIMI-38 [Trial to Assess Improvement in Therapeutic Outcomes by Optimizing Platelet Inhibition with Prasugrel-TIMI-38]) [29]. Wykazano większą skuteczność tikagreloru i prasugrelu w porównaniu z klopidogrelem w zmniejszaniu częstości występowania niepożądanych zdarzeń sercowych i ponownego zawału serca, bez znaczących różnic między tymi dwoma lekami. W porównaniu z klopidogrelem stosowanie tikagreloru wiązało się ze zmniejszeniem częstości zgonu z dowolnej przyczyny i z przyczyn sercowo-naczyniowych, nie stwierdzono natomiast różnic pod tym względem między klopidogrelem i prasugrelem. Wykazano, że wśród inhibitorów $\mathrm{P}_{2 Y_{12}}$ najbardziej skutecznym i najbezpieczniejszym lekiem jest tikagrelor.

\section{Tikagrelor w codziennej praktyce klinicznej - rejestry europejskie}

Większą skuteczność tikagreloru w porównaniu z klopidogrelem potwierdzono też poza badaniami klinicznymi z udziałem wyselekcjonowanych chorych, w warunkach dużych populacji, na przykład wykorzystano dane ze szwedzkiego ogólnonarodowego rejestru SWEDEHEART (the Swedish Web-system for Enhancement and Development of Evidence-based care in Heart disease Evaluated According to Recommended Therapies), do którego wprowadza się informacje na temat wszystkich osób przyjętych do szpitali w Szwecji z podejrzeniem ACS [30]. Przeprowadzono prospektywne, kohortowe badanie z udziałem 45073 pacjentów z ACS, którzy zostali wypisani do domu z zaleceniem przyjmowania tikagreloru (11 954 osoby) lub klopidogrelu (33 119) w połączeniu z ASA (75 mg). Pierwszorzędowy złożony punkt końcowy (zgon z wszystkich przyczyn, ponowne przyjęcie do szpitala z powodu zawału serca lub udaru mózgu) w ciągu 24 miesięcy obserwacji wystąpił u 11,7\% chorych przyjmujących tikagrelor i 22,3\% stosujących klopidogrel (HR 0,85, 95\% Cl 0,78-0,93), zgon stwierdzono u 5,8\% w porównaniu z 12,9\% (HR 0,83, 95\% Cl 0,75-0,92), zawał serca u 6,1\% w porównaniu z 10,8\% (HR 0,89, 95\% Cl 0,78-1,01), a udar mózgu u 1,8\% versus 3,8\% (HR 0,81, 95\% Cl 0,65-1,01). Odnotowano także częstość występowania krwawienia u osób, które z tego powodu trafiły do szpitala: w grupie przyjmującej tikagrelor odnotowane je u 5,5\% osób, w grupie przyjmującej klopidogrel u 5,2\% (HR 1,20, 95\% Cl 1,04-1,40). W podgrupie pacjentów poddawanych $\mathrm{PCl}$ krwawienia podczas tej procedury stwierdzono u 3,7\% badanych otrzymujących tikagrelor i 2,7\% klopidogrel (iloraz szans [OR, odds ratio] 1,57, 95\% Cl 1,30-1,90).

Dokonano także analizy terapii za pomocą tikagreloru i klopidogrelu w populacji z zawałem serca z rejestru SWEDEHEART (45 206 osób - 33472 otrzymywały po wypisaniu ze szpitala klopidogrel i 11734 tikagrelor) pod kątem szacunkowego współczynnika filtracji kłębuszkowej (eGFR, estimated glomerular filtration rate) [31]. Chorych podzielono na następujące grupy: z eGFR powyżej 60, z eGFR 30- 60 i z eGFR poniżej 30. Wykazano, że we wszystkich grupach leczenie tikagrelorem wiązało się z rzadszym występowaniem pierwszorzędowego punktu końcowego (zgon, zawał serca, udar mózgu) w ciągu 12 miesięcy obserwacji. Częstość występowania pierwszorzędowego punktu końcowego (bez uwzględnienia innych czynników) wyniosła dla odpowiednich przedziałów eGFR w grupie przyjmującej tikagrelor: 7,0\%, 18,0\% i 48,0\%, w porównaniu z 11,0\%, 33,0\% i 64,0\% w grupie przyjmującej klopidogrel. Po dostosowaniu wyników stwierdzono, że w porównaniu ze stosowaniem klopidogrelu przyjmowanie tikagreloru wiązało się z rzadszym występowaniem pierwszorzędowego punktu końcowego (eGFR > 60: HR 0,87, 95\% Cl 0,76-0,99; eGFR 30-60: HR 0,82, 95\% Cl 0,70-0,97; eGFR < 30: HR 0,95, 95\% Cl 0,69-1,29; $\mathrm{p}$ dla interakcji $=0,55)$. W grupie leczonej tikagrelorem stwierdzono także częstsze występowanie krwawień, niezależnie od wartości eGFR (eGFR > 60: HR 1,10, 95\% Cl 0,90-1,35; eGFR 30-60: HR 1,13, 95\% Cl 0,84-1,51; eGFR < 30: HR 1,79, 95\% Cl 1,00-3,21; p dla interakcji $=0,30)$. Częstsze występowanie krwawień stwierdzano zwłaszcza u pacjentów z eGFR poniżej 30.

Dane na temat dużej populacji chorych wykorzystano też w badaniu AREMIS (The Antiplatelet agents and Recurrent Myocardial Infarction Study) [32]. Dokonano 
w nim analizy danych pochodzących z francuskiego rejestru chorych z ACS dotyczących 1047 osób, które przeszły ponowny zawał serca, i 2234 osób z ACS bez ponownego zawału. Porównano skuteczność tikagreloru i prasugrelu ze skutecznością klopidogrelu w zapobieganiu ponownemu zawałowi serca zarówno zakończonemu, jak i niezakończonemu zgonem. Czas obserwacji wynosił 12 miesięcy. Stwierdzono znaczące zmniejszenie ryzyka ponownego zawału serca podczas przyjmowania tikagreloru w porównaniu z przyjmowaniem klopidogrelu (dla tikagreloru: OR 0,65, 95\% Cl 0,52-0,81). Otrzymane wyniki wskazywały większą skuteczność tikagreloru w zapobieganiu ponownemu zawałowi serca niż stwierdzono to w badaniach klinicznych, na przykład w badaniu PLATO.

\section{Zastosowanie tikagreloru w polskich ośrodkach}

Według danych pochodzących z 122 polskich ośrodków kardiologii interwencyjnej (ORPKI, Ogólnopolski Rejestr Procedur Kardiologii Inwazyjnej) zebranych od września 2015 roku do sierpnia 2016 u 69\% z populacji 19437 pacjentów ze STEMI stosowano klopidogrel, który w 51,3\% przypadków podano, zanim pacjent dotarł do pracowni hemodynamicznej [33]. Tikagrelor otrzymało 10,1\% pacjentów ze STEMI (2,3\% przed dotarciem do pracowni hemodynamicznej). Rzadko dokonywano też zamiany klopidogrelu na inhibitor $\mathrm{P}_{2} \mathrm{Y}_{12}$ nowej generacji podczas samego zabiegu $\mathrm{PCl}$ (zamiana na tikagrelor u $2 \%$ badanych).

Z dotyczącej 185 pacjentów analizy danych receptowych przedstawionej w serwisie RECEPTOmetr PEX wynika, że 37\% pacjentów przerywa terapię tikagrelorem po miesiącu (po 3 miesiącach ponad 50\%) [34]. Po przerwaniu terapii tikagrelorem $57 \%$ osób nie stosuje klopidogrelu. Przytoczone dane należy potraktować jako alarmujące. Już od kilku lat zajmujący najwyższą pozycję w zaleceniach dotyczących terapii chorych z ACS (STEMI i NSTEMI) tikagrelor (klasa zaleceń I, rekomendowane zastosowanie przed klopidogrelem) bardzo rzadko stosuje się w naszym kraju, w przeważającej liczbie przypadków wbrew standardom wybierana jest i podtrzymywana terapia klopidogrelem. Notuje się z kolei niebezpieczną tendencję zbyt szybkiego odstawiania tikagreloru i pozostawanie chorego bardzo wysokiego ryzyka sercowo-naczyniowego bez obowiązującej terapii przeciwpłytkowej. Tikagrelor jest jedynym inhibitorem $\mathrm{P}_{2} \mathrm{Y}_{12}$, o udowodnionej redukcji ryzyka zgonów sercowo-naczyniowych, bezpiecznym dla każdego pacjenta z ACS, niezależnie od przyjętej strategii leczenia (PCI, leczenie zachowawcze, CABG). Terapia powinna być kontynuowana przez 12 miesięcy (chyba że istnieją przeciwwskazania). Nie należy pozbawiać pacjenta możliwości wyboru, a jego decyzję odnotować w historii choroby stosownym wpisem.

\section{Podziękowania}

Autorka składa podziękowania dla Proper Medical Writing za pomoc w przygotowaniu artykułu.

\section{Konflikt interesów}

Honoraria za wykłady dla firm: Egis, Krka, MSD, Mylan, Servier.

\section{Abstract}

Dual antiplatelet therapy, composed of aspirin plus a $\mathrm{P} 2 \mathrm{Y}_{12}$-receptor antagonist, is currently the standard for the management of acute coronary syndrome (ACS). Ticagrelor, a representative of a new group of antiplatelet agents, is a non-competitive, direct-acting receptor antagonist. In pharmacodynamic studies, ticagrelor demonstrated faster onset and more potent inhibition of platelet aggregation than clopidogrel. The efficacy and safety of ticagrelor vs clopidogrel has been proven in a randomised study [(16\% reduction in cardiovascular deaths, $\mathrm{MI}$ and strokes (hazard ratio $\{\mathrm{HR}\}$ $0.84 ; 95 \%$ confidence interval $\{\mathrm{Cl}\}$ 0.77-0.92), 21\% reduction in cardiovascular mortality (HR 0.79; 95\% Cl 0.69-0,91; $p=0.001)$, and no statistically significant differences in major bleeds vs clopidogrel (11.6\% vs $11.2 \% ; p=0.43)$, as well as in the RWE Swedeheart registry. According to the current guidelines of the European Society of Cardiology, the choice of ticagrelor rather than other $\mathrm{P}_{2} \mathrm{Y}_{12}$ receptor inhibitors is recommended regardless of whether the initial treatment strategy is conservative, invasive or surgery.

Key words: ticagrelor, acute coronary syndrome

Folia Cardiologica 2018; 13, 5: 442-449 


\section{Piśmiennictwo}

1. Gąsior M, Poloński L, Gierlotka M. Korzyści z inwazyjnego leczenia zawału serca - niech przemówią wielkie liczby. Materiały z XXIV Międzynarodowej Konferencji Kardiologicznej „Postępy w rozpoznawaniu i leczeniu chorób serca”. Zabrze, 7-9 czerwca 2017.

2. Brieger D, Eagle KA, Goodman SG, et al. GRACE Investigators. Acute coronary syndromes without chest pain, an underdiagnosed and undertreated high-risk group: insights from the Global Registry of Acute Coronary Events. Chest. 2004; 126(2): 461-469, doi: 10.1378/ /chest.126.2.461, indexed in Pubmed: 15302732.

3. Kaul P, Armstrong PW, Sookram S, et al. Temporal trends in patient and treatment delay among men and women presenting with ST-elevation myocardial infarction. Am Heart J. 2011; 161(1): 91-97, doi: 10.1016/j.ahj.2010.09.016, indexed in Pubmed: 21167339.

4. Diercks DB, Owen KP, Kontos MC, et al. Gender differences in time to presentation for myocardial infarction before and after a national women's cardiovascular awareness campaign: a temporal analysis from the Can Rapid Risk Stratification of Unstable Angina Patients Suppress ADverse Outcomes with Early Implementation (CRUSADE) and the National Cardiovascular Data Registry Acute Coronary Treatment and Intervention Outcomes Network-Get with the Guidelines (NCDR ACTION Registry-GWTG). Am Heart J. 2010; 160(1): 80-87.e3, doi: 10.1016/j.ahj.2010.04.017, indexed in Pubmed: 20598976.

5. Kawecki D, Gierlotka M, Morawiec B, et al. Direct admission versus interhospital transfer for primary percutaneous coronary intervention in ST-segment elevation myocardial infarction. JACC Cardiovasc Interv. 2017; 10(5): 438-447, doi: 10.1016/j.jcin.2016.11.028, indexed in Pubmed: 28216215.

6. Puymirat E, Simon T, Steg PG, et al. USIK USIC 2000 Investigators, FAST MI Investigators. Association of changes in clinical characteristics and management with improvement in survival among patients with ST-elevation myocardial infarction. JAMA. 2012; 308(10): 998-1006, doi: 10.1001/2012.jama.11348, indexed in Pubmed: 22928184.

7. Gale CP, Allan V, Cattle BA, et al. Trends in hospital treatments, including revascularisation, following acute myocardial infarction, 2003-2010: a multilevel and relative survival analysis for the National Institute for Cardiovascular Outcomes Research (NICOR). Heart. 2014; 100(7): 582-589, doi: 10.1136/heartjnl-2013-304517, indexed in Pubmed: 24436220.

8. Badimon L, Padró T, Vilahur G. Atherosclerosis, platelets and thrombosis in acute ischaemic heart disease. Eur Heart J Acute Cardiovasc Care. 2012; 1(1): 60-74, doi: 10.1177/2048872612441582, indexed in Pubmed: 24062891.

9. Siller-Matula JM, Krumphuber J, Jilma B. Pharmacokinetic, pharmacodynamic and clinical profile of novel antiplatelet drugs targeting vascular diseases. Br J Pharmacol. 2010; 159(3): 502-517, doi: 10.1111/j.1476-5381.2009.00555.x, indexed in Pubmed: 20050853.

10. Roffi M, Patrono C, Collet JP, et al. Wytyczne ESC dotyczące postępowania w ostrych zespołach wieńcowych bez przetrwałego uniesienia odcinka ST w 2015 roku. Kardiol Pol. 2015; 73(12): 1207-1294, doi: 10.5603/kp.2015.0243.

11. Ibanez B, James S, Agewall S, et al. 2017 ESC Guidelines for the management of acute myocardial infarction in patients presenting with ST-segment elevation. Kardiol Pol. 2018; 76(2): 229-313, doi: 10.5603/kp.2018.0041.

12. Valgimigli M, Bueno $\mathrm{H}$, Byrne R, et al. Uaktualnione stanowisko ESC dotyczące stosowania podwójnej terapii przeciwpłytkowej w chorobie wieńcowej w 2017 roku, przygotowane we współpracy z EACTS. Kardiol Pol. 2017; 75(12): 1217-1299, doi: 10.5603/kp.2017.0224.

13. Molska M, Grąbczewska Z, Kubica A. Doustne inhibitory płytkowego receptora P2Y12. Acta Angiol. 2014; 20(4): 158-162.

14. Gurbel PA, Bliden KP, Butler K, et al. Randomized double-blind assessment of the ONSET and OFFSET of the antiplatelet effects of ticagrelor versus clopidogrel in patients with stable coronary artery disease: the ONSET/OFFSET study. Circulation. 2009; 120(25): 2577-2585, doi: 10.1161/CIRCULATIONAHA.109.912550, indexed in Pubmed: 19923168.

15. Sibbing D, Stegherr J, Latz W, et al. Cytochrome P450 2 C19 loss-of-function polymorphism and stent thrombosis following percutaneous coronary intervention. Eur Heart J. 2009; 30(8): 916-922, doi: 10.1093/eurheartj/ehp041, indexed in Pubmed: 19193675.

16. Siller-Matula JM, Trenk D, Schrör K, et al. EPA (European Platelet Academy). Response variability to $\mathrm{P} 2 \mathrm{Y} 12$ receptor inhibitors: expectations and reality. JACC Cardiovasc Interv. 2013; 6(11): 1111-1128, doi: 10.1016/j.jcin.2013.06.011, indexed in Pubmed: 24262612.

17. Gurbel PA, Bliden KP, Butler K, et al. Response to ticagrelor in clopidogrel nonresponders and responders and effect of switching therapies: the RESPOND study. Circulation. 2010; 121(10): 1188-1199, doi: 10.1161/CIRCULATIONAHA.109.919456, indexed in Pubmed: 20194878

18. Wallentin L, Becker RC, Budaj A, et al. PLATO Investigators. Ticagrelor versus clopidogrel in patients with acute coronary syndromes. N Eng| J Med. 2009; 361(11): 1045-1057, doi: 10.1056/NEJMoa0904327, indexed in Pubmed: 19717846.

19. Lindholm D, Varenhorst C, Cannon CP, et al. Ticagrelor vs. clopidogrel in patients with non-ST-elevation acute coronary syndrome with or without revascularization: results from the PLATO trial. Eur Heart J. 2014; 35(31): 2083-2093, doi: 10.1093/eurheartj/ehu160, indexed in Pubmed: 24727884.

20. Steg PG, James S, Harrington RA, et al. PLATO Study Group. Ticagrelor versus clopidogrel in patients with ST-elevation acute coronary syndromes intended for reperfusion with primary percutaneous coronary intervention: a Platelet Inhibition and Patient Outcomes (PLATO) trial subgroup analysis. Circulation. 2010; 122(21): 2131-2141, doi: 10.1161/CIRCULATIONAHA.109.927582, indexed in Pubmed: 21060072.

21. Cannon CP, Harrington RA, James S, et al. PLATelet inhibition and patient Outcomes Investigators. Comparison of ticagrelor with clopidogrel in patients with a planned invasive strategy for acute coronary syndromes (PLATO): a randomised double-blind study. Lancet. 2010; 375(9711): 283-293, doi: 10.1016/S0140-6736(09)62191-7, indexed in Pubmed: 20079528.

22. James SK, Roe MT, Cannon CP, et al. PLATO Study Group. Ticagrelor versus clopidogrel in patients with acute coronary syndromes intended for non-invasive management: substudy from prospective randomised PLATelet inhibition and patient Outcomes (PLATO) trial. BMJ. 2011; 342: 1-11, indexed in Pubmed: 21685437.

23. Husted S, James S, Becker RC, et al. PLATO study group. Ticagrelor versus clopidogrel in elderly patients with acute coronary syndromes: a substudy from the prospective randomized PLATelet inhibition and patient Outcomes (PLATO) trial. Circ Cardiovasc Qual Outcomes. 2012; 5(5): 680-688, doi: 10.1161/CIRCOUTCOMES.111.964395, indexed in Pubmed: 22991347.

24. James S, Angiolillo DJ, Cornel JH, et al. PLATO Study Group. Ticagrelor vs. clopidogrel in patients with acute coronary syndromes and diabe- 
tes: a substudy from the PLATelet inhibition and patient Outcomes (PLATO) trial. Eur Heart J. 2010; 31(24): 3006-3016, doi: 10.1093/ /eurheartj/ehq325, indexed in Pubmed: 20802246.

25. James S, Budaj A, Aylward P, et al. Ticagrelor versus clopidogrel in acute coronary syndromes in relation to renal function: results from the Platelet Inhibition and Patient Outcomes (PLATO) trial. Circulation. 2010; 122(11): 1056-1067, doi: 10.1161/CIRCULATIONAHA.109.933796, indexed in Pubmed: 20805430.

26. Bonaca MP, Bhatt DL, Cohen M, et al. PEGASUS-TIMI 54 Steering Committee and Investigators. Long-term use of ticagrelor in patients with prior myocardial infarction. N Engl J Med. 2015; 372(19): 1791-1800, doi: 10.1056/NEJMoa1500857, indexed in Pubmed: 25773268.

27. Dellborg M, Bonaca MP, Storey RF, et al. Efficacy and safety with ticagrelor in patients with prior myocardial infarction in the approved European label: insights from PEGASUS-TIMI 54. Eur Heart J. 2017; 38(Suppl 1): 794, doi: 10.1093/eurheartj/ehx504.p3670.

28. Bonaca MP, Bhatt DL, Steg PG, et al. Ischaemic risk and efficacy of ticagrelor in relation to time from $\mathrm{P} 2 \mathrm{Y} 12$ inhibitor withdrawal in patients with prior myocardial infarction: insights from PEGASUS-TIMI 54. Eur Heart J. 2016; 37(14): 1133-1142, doi: 10.1093/eurheartj/ehv531, indexed in Pubmed: 26491109.

29. Shah R, Rashid A, Hwang I, et al. Meta-Analysis of the relative efficacy and safety of oral p2y12 inhibitors in patients with acute coronary syndrome. Am J Cardiol. 2017; 119(11): 1723-1728, doi: 10.1016/j. amjcard.2017.03.011, indexed in Pubmed: 28385176.

30. Sahlén A, Varenhorst C, Lagerqvist Bo, et al. Outcomes in patients treated with ticagrelor or clopidogrel after acute myocardial infarction: experiences from SWEDEHEART registry. Eur Heart J. 2016; 37(44): 3335-3342, doi: 10.1093/eurheartj/ehw284.

31. Edfors R, Sahlén A, Szummer K, et al. Outcomes in patients treated with ticagrelor versus clopidogrel after acute myocardial infarction stratified by renal function. Heart. 2018; 104(19): 1575-1582, doi: 10.1136/heartjnl-2017-312436, indexed in Pubmed: 29574413.

32. Grimaldi-Bensouda L, Danchin N, Dallongeville J, et al. PGRx-Acute Coronary Syndrome Study Group. Effectiveness of new antiplatelets in the prevention of recurrent myocardial infarction. Heart. 2018; 104(19): 1583-1592, doi: 10.1136/heartjnl-2017-312534, indexed in Pubmed: 29535227.

33. Rakowski T, Siudak Z, Dziewierz A, et al. Contemporary use of P2Y inhibitors in patients with ST-segment elevation myocardial infarction referred to primary percutaneous coronary interventions in Poland: Data from ORPKI national registry. J Thromb Thrombolysis. 2018; 45(1): 151-157, doi: 10.1007/s11239-017-1579-9, indexed in Pubmed: 29075924.

34. Analiza danych receptowych - panel RECEPTOmetrPEX. Informacje o środowisku lekarzy opracowane zostały na podstawie bazy HDM Polska sp. z 0.0. Grupa FarmaProm. www.hdm.pl (14.10.2018). 